\title{
HOW TO MASTER GENERIC SKILLS IN THE ENGLISH LANGUAGE? AN ELECTRONIC-PROBLEM-BASED LEARNING WAY: A MALAYSIAN EXPERIENCE
}

\author{
${ }^{1}$ Assoc Prof Dr Berhannudin Mohd Salleh, Universiti Tun Hussein Onn Malaysia \\ berhan@uthm.edu.my \\ ${ }^{2}$ Assoc . Prof Dr Ashley Edward Soosay, Universiti Malaysia Sarawak, Malaysia \\ sashley@unimas.edu.my
}

\author{
${ }^{3}$ Assoc Prof Dr Hussain Othman, Universiti Tun Hussein Onn Malaysia \\ ${ }^{4}$ Assoc Prof Dr Ahmad Esa, Universiti Tun Hussein Onn Malaysia \\ ${ }^{5}$ Assoc Prof Dr Asri Selamat, Universiti Tun Hussein Onn Malaysia \\ ${ }^{6}$ Assoc Prof Dr Khairul Azman Mohamad,Universiti Tun Hussein Onn Malaysia \\ ${ }^{7}$ Dr Zulida Abdul Kadir, Universiti Tun Hussein Onn Malaysia \\ ${ }^{8}$ Dr Elizabeth d/o Anthony, Universiti Tun Hussein Onn Malaysia \\ ${ }^{9}$ Robijah Kamarolzaman, Universiti Tun Hussein Onn Malaysia \\ ${ }^{10}$ Zainal Abidin Sayadi, Universiti Tun Hussein Onn Malaysia \\ ${ }^{11}$ Mohammad Talha Mohamed Idris, Universiti Tun Hussein Onn Malaysia \\ ${ }^{12}$ Abdullah Sulaiman, Universiti Tun Hussein Onn Malaysia \\ ${ }^{13}$ Farhana Hamin, Universiti Tun Hussein Onn Malaysia
}

\begin{abstract}
Does it matter in whatever language a student acquires generic skills? The answer is, YES it matters a lot. The reality is that other than the content area or the hard skill, competence in generic skills AND communication in the English language among undergraduates are also of utmost importance, if they are to achieve academic excellence and more importantly secure employment upon graduation. Stakeholders including parents, sponsoring bodies, the community and especially the employers have high expectations on the university to produce graduates who not only excel in the content matter but equally important possess mastery of communication skills in English and generic skills. Unfortunately, the current scenario in Malaysia is not so encouraging. The lack of competence in English and generic skills among graduates in Malaysia have been the two major contributing factors for their unemployment (Ministry of Higher Education, Malaysia, 2015) so much so that almost half of Malaysian graduates were unemployed (The Star Online, 2013) and 400 thousand Malaysian graduates were unemployed in 2015 (Bernama, 2015 cited in The Malaysian Insider, 2015). The nation has long been asking WHY? Despite the 17 years of education from kindergarten to university level, Malaysia is still grappling with producing graduates who are not only proficient in the English language but basic generic skills like citizenship, honesty, passion, knowledge transfer, critical thinking, perseverance, IT and problem-solving. This paper reveals the findings of a study on the use of Electronic-Problem-Based Learning (ePBL) towards enhancing learning of communication and
\end{abstract}


generic skills in the English Language among Malaysian undergraduates. Using purposeful sampling, the samples involved 223 undergraduates and 12 lecturers from Universiti Tun Hussein Onn Malaysia and Universiti Malaysia Sarawak. The samples were treated with ePBL in their semester long studies; Effective Communication in English (UTHM) and Health Science (UNIMAS). Data was collected using a questionnaire set administered online and interview with both the students and lecturers. The findings show that the use of ePBL has a very positive effect in enhancing learning of the English Language and generic skills among the undergraduates. On the part of the lecturers, the approach has also open up new and more interesting ways of training future graduates who are both competent in the hard and soft skills areas much to the expectations of the nation in general. As a conclusion, ePBL has proven to be very instrumental towards improving learning and there is great potential for the approach to be adopted in other disciplines and the education system at all levels.

Keywords: E-learning, Communication, English, Foreign Language Education, ESL/TESL, PBL, Generic, Soft, Higher Education, New Technologies in Education

\section{BACKGROUND OF STUDY}

In Malaysia, the importance of English is undeniably crucial. It is not just a language for academic and social purposes but equally important is the language is widely and must be effectively used in the working industry both the public and the private enterprises. The status of English is considered a second language after the national language, Bahasa Malaysia. It is widely used in almost all aspects of the Malaysian life. Academically, the subject is compulsory and taught as a Second Language (ESL) at schools and tertiary institutions and in the context of this study English is a compulsory subject and a medium of instruction for the many subjects offered at university.

One of the main reasons for the importance of English is because most employers prefer their staff to be able to speak and write English fluently. Many multi-national companies in Malaysia who need Malaysian work force are on the lookout for those who are proficient in English, as they are going to deal on the international level. In a survey done by an online recruitment company, JobStreet.com, Malaysia is placed third compared to five other countries in South East Asia on the English proficiency level (The Malaysian Times, 2013)

In a market survey on industrial needs conducted for the Ministry of Higher Education, it was found out that employers indicated that most jobs call not only for knowledge and specific technical competencies, but also for a certain level of communication in English. They also emphasize for the mastery of English among graduates because it is the most important language of communication in Malaysia especially in the private sector (Prestariang Systems, 2011)

According to a more recent survey conducted by Jobstreet (Malay Mail Online, 2016), employers are more likely to hire based on a fresh graduate's positive personality and command of English rather than where he obtained his university qualifications, a recent survey by employment website Jobstreet.com suggests.

Malaysia's language policy has traditionally singled out Bahasa Malaysia and English as the most important language languages to help steer the country towards becoming a fully developed nation by 2020 . Taking note of its multi-racial and religious society, Bahasa Malaysia is considered the language of national integration while English is that of working language for international contribution. In accordance with Vision 2020, Malaysia's national project to develop the country as an advanced ICT base by the year 2020, English Language Teaching (ELT) is further emphasized as the key to its success (JACET, 2016)

Another equally crucial component of the Malaysian recipe towards achieving Vision 2020 (EPU, 2016) is the abundance supply of a strong workforce highly competent not only in the hard skills but the soft skills or Generic Skills (GS). There is no one definitive definition of GS. Simply, they are skills that are transferable to be applied in a variety of subject-domains (Reiguluth, 2000). According to the Australian National Training Authority (2003), GSs are those that apply across a variety of jobs and life contexts. They are also known by several other names, including key skills, core skills, essential skills, key competencies, necessary skills, transferable skills and employability skills. Industry's preferred term is employability skills. Some of the skills studied here are leadership, problem-solving, perseverance, critical thinking and communication.

The equally, if not more, important reason for the infusion of GSs in Malaysian higher education in 2006 was due to criticisms from employers that Malaysian graduates are generally academically proficient but lack in GSs such as communication and analytical skills. Secondly, the increasing globalization of the work force 
and job market imposes much more competitive skills on our graduates whereby big international and multinational companies are continually seeking employees who, apart from being highly qualified technically, also possess leadership and good communication skills (Roselina, 2009).

\section{STATEMENT OF PROBLEM}

Despite all the noble aims and efforts undertaken, in reality all is not so rosy. A survey involving 1000 respondents by Jobstreet in 2013 reported that deficiencies in interpersonal skills $(60 \%)$ and language mastery (55\%) to be the second and third most-frequently cited reason for why fresh graduates' are not hired. It further reported that the number one reason, at $67 \%$, for companies turning them down is "unrealistic pay demands" given their inexperience. In addition, almost two-thirds of hirers were not particular about which universities the graduates attended, or whether these were public or private institutions (Malay Mail Online, 2016). The situation was so alarming that there was a very high unemployment rate of about 40,000 undergraduates mainly due to their weakness in the English language (The Star Online, 2012).

A national study commissioned by the Ministry of Higher Education in 2007 (Prestariang Systems, 2007) revealed that more than $54 \%$ of undergraduates from 6 universities in Malaysia were considered limited users of English. Overall, 58\% were considered limited users of English in writing, while $77 \%$ were limited users of English in speaking. Due to poor English competency in the productive skills, many Malaysian graduates, more often than not, are unable to present ideas and explain issues in writing, verbally, and in group discussions; to write reports, project papers, proposals and minutes of meeting; and to negotiate and convey ideas in planned and impromptu situations

Another crucial aspect that our graduates lack for their failure to secure jobs is GSs. According to Deputy Vice-chancellor of Taylor's University Dr Pradeep Nair, "The expectation that employers have are not just about a degree. The problem of unemployment has largely to do with soft skills, life skills and emotional wellbeing". The lack or poor mastery of GSs is one of the major reasons for the huge unemployment rate as figured earlier. Meanwhile, a study conducted by Universiti Kebangsaan Malaysia reveals that the general consensus among Malaysian employers indicates that Malaysian graduates are well trained in their areas of specialization but unfortunately they lack the 'soft skills', such as communication, problem solving, interpersonal and the ability to be flexible (Nurita et al., 2004; Suresh, 2006; Mohamad Sattar et al., 2009; Nur Atiqah et al., 2006 cited in Nik Hairi Omar, Rusyda Helma Mohd and Che Arena, 2012).

\section{OBJECTIVES}

This paper thus presents the findings of a study from a bigger study on the use of Electronic Problem-Based Learning (ePBL) towards enhancing learning of the English language and GSs among undergraduates of Malaysian public universities (PUs).

\section{ELECTRONIC PROBLEM-BASED LEARNING}

\subsection{Problem-Based Learning}

PBL can be thought of as a combination of cognitive and social constructivist theories, as developed by Piaget and Vygotsky, respectively. The major points of each of these theories are outlined in the table as in Appendix A (Samford University, 2016)

Problem-Based Learning (PBL) is a unique pedagogy that is dynamic and requires students in small groups to experience active learning initiated by real world problems or triggers assigned to them to be explored and solved. According to Barrows (1999), Problem-Based Learning (PBL) is an authentic, multidisciplinary approach to education that challenges students to learn through an active engagement using real life problems. In actual fact, it is how learning should take place whereby the primary objective and emphasis is to enable students to LEARN to LEARN as opposed to mere teaching by teachers. Learning assessment is and must be both formative and summative encompassing content or product and process. The student's role is more prominent here while the teacher or lecturer plays the role of a facilitator.

\subsection{E-Learning}

Meanwhile, e-learning is electronic learning, and typically this means using a computer to deliver part, or all of a course whether it's in a school, part of your mandatory business training or a full distance learning course (Virtual College, 2016). 


\subsection{Electronic Problem-Based Learning}

Electronic Problem-Based Learning (ePBL) is thus an evolution of Problem-Based Learning (Barrows, 1999) but synthesized with eLearning (Virtual College, 2016). In ePBL, the tools used involved both Internet and non-Internet electronic applications all easily and commonly available to students either online or stand-alone (e.g. Schoology, Facebook, Web, Microsoft PowerPoint, mobile phones, videos)

\section{METHODOLOGY}

Using purposeful sampling (Patton, 1990), 223 undergraduates from Universiti Tun Hussein Onn Malaysia (UTHM) and Universiti Malaysia Sarawak (UNIMAS) participated in this ePBL project for one semester. Those from UTHM comprised engineering, management, science and information technology students studying the compulsory English language course, Effective Communication (EC), while UNIMAS were medical students who studied Health Science in English as part of their medical program. All these subjects especially EC require students to learn about the target language and conduct meetings, negotiation, documentation, presentation as well as community engagement in general.

In small groups, these students conducted community projects (Hygiene, Anti-Smoking, Academic Excellence, Caring for the Old, Environmental Awareness and many others) within their respective community necessitating them to work together among themselves, with the university administrative staff and of course with the target community towards solving real world problem. In the process, students' engaged in a lot of learning activity like discussion, site visit, research, proposal, blog, documentation, presentation, brainstorming and execution of the project.

\section{FINDINGS}

Upon completion of their respective projects and courses, the students shared their views and experiences using a set of questionnaire conducted on google.doc. Table 1 and 2 below illustrate the results for ELS and GSs.

\subsection{English Language}

Table 2: Respondents' English language proficiency at the beginning and end of the semester

\begin{tabular}{|l|l|c|c|c|c|c|c|}
\hline \multirow{2}{*}{ NO } & \multicolumn{2}{|c|}{ ITEM } & \multicolumn{3}{c|}{ BEGINNING } & \multicolumn{3}{c|}{ END } \\
\cline { 3 - 8 } & & Mean & SD & $\begin{array}{c}\text { Mean } \\
\text { Score }\end{array}$ & Mean & SD & $\begin{array}{c}\text { Mean } \\
\text { Score }\end{array}$ \\
\hline a. & Fluency & 2.95 & 0.682 & Average & 3.57 & 0.632 & Average \\
\hline b. & Grammar & 2.89 & 0.723 & Average & 3.49 & 0.663 & Average \\
\hline c. & Vocabulary & 2.94 & 0.705 & Average & 3.57 & 0.653 & Average \\
\hline d. & Oral presentation & 2.90 & 0.747 & Average & 3.68 & 0.713 & High \\
\hline e. & $\begin{array}{l}\text { Online discussion / } \\
\text { meeting }\end{array}$ & 3.03 & 0.779 & Average & 3.69 & 0.698 & High \\
\hline f. & $\begin{array}{l}\text { Face-to-face discussion } \\
\text { / meeting }\end{array}$ & 3.05 & 0.763 & Average & 3.75 & 0.683 & High \\
\hline g. & Normal reading & 3.44 & 0.757 & Average & 3.91 & 0.679 & High \\
\hline h. & Online reading & 3.40 & 0.821 & Average & 3.87 & 0.686 & High \\
\hline i. & Normal writing & 3.13 & 0.741 & Average & 3.64 & 0.690 & Average \\
\hline j. & Online writing & 3.09 & 0.720 & Average & 3.63 & 0.697 & Average \\
\hline k. & Listening & 3.25 & 0.759 & Average & 3.79 & 0.661 & High \\
\hline & \multicolumn{1}{|c|}{ Total } & $\mathbf{3 . 1 0}$ & $\mathbf{0 . 7 4 5}$ & Average & $\mathbf{3 . 6 9}$ & $\mathbf{0 . 6 7 8}$ & High \\
\hline
\end{tabular}

(Source: B. Mohd Salleh et al, 2015) 
At the beginning of the semester, respondent's English proficiency was average with a mean score of 3.10 and SD 0.745. The highest was Normal Reading with a mean score of 3.40 and SD 0.821 . The lowest was grammar with a mean score 2.89 and SD 0.723 . At the end of the semester, respondent's English proficiency was high with a mean score of 3.69 and SD 0.678 . The highest mean score was for normal reading with a mean score 3.91 and SD 0.679. The lowest was for grammar with a mean score 3.49 and SD 0.663. Using $t$-test, where $t=17.913$ and $p=0.00$ the findings show there is significant difference in the comparison made.

\subsection{Generic Skills}

Table 3: Generic Skills at the Beginning and End of the Semester

\begin{tabular}{|c|c|c|c|c|c|c|c|}
\hline & & \multicolumn{3}{|c|}{ BEGINNING } & \multicolumn{3}{|c|}{ END } \\
\hline No. & Item & Mean & SD & $\begin{array}{l}\text { Mean } \\
\text { Score }\end{array}$ & Mean & SD & $\begin{array}{l}\text { Mean } \\
\text { Score }\end{array}$ \\
\hline a. & Communication & 3.00 & 0.735 & Average & 3.80 & 0.605 & High \\
\hline b. & Critical thinking & 3.00 & 0.723 & Average & 3.79 & 0.631 & High \\
\hline c. & Problem solving & 3.09 & 0.736 & Average & 3.81 & 0.637 & High \\
\hline d. & Team work & 3.27 & 0.806 & Average & 4.00 & 0.664 & High \\
\hline e. & Leadership & 3.06 & 0.745 & Average & 3.82 & 0.674 & High \\
\hline f. & Confidence & 3.04 & 0.802 & Average & 3.88 & 0.681 & High \\
\hline g. & $\begin{array}{l}\text { Moral \& Professional } \\
\text { ethics }\end{array}$ & 3.22 & 0.804 & Average & 3.85 & 0.647 & High \\
\hline h. & Entrepreneurship & 2.95 & 0.769 & Average & 3.62 & 0.718 & Average \\
\hline i. & Lifelong learning & 3.11 & 0.795 & Average & 3.84 & 0.649 & High \\
\hline j. & $\begin{array}{l}\text { Information } \\
\text { management }\end{array}$ & 3.09 & 0.750 & Average & 3.78 & 0.614 & High \\
\hline k. & $\begin{array}{l}\text { Social } \\
\text { consciousness }\end{array}$ & 3.10 & 0.761 & Averaqe & 3.80 & 0.655 & High \\
\hline I. & $\begin{array}{l}\text { Social interaction } \\
\text { (socializing with the } \\
\text { community) }\end{array}$ & 3.09 & 0.792 & Average & 3.81 & 0.674 & High \\
\hline m & $\begin{array}{l}\text { Inquisitiveness } \\
\text { (Curiosity) }\end{array}$ & 3.13 & 0.801 & Average & 3.82 & 0.656 & High \\
\hline $\mathbf{n}$ & Perseverance & 3.07 & 0.726 & Average & 3.74 & 0.620 & High \\
\hline 0 & $\begin{array}{l}\text { Creativity \& } \\
\text { innovation }\end{array}$ & 3.09 & 0.715 & Average & 3.79 & 0.652 & High \\
\hline$p$ & Others & 2.61 & 1.047 & Average & 3.17 & 1.196 & Average \\
\hline & Total & 3.06 & 0.782 & Average & 3.77 & 0.686 & High \\
\hline
\end{tabular}

Respondent's generic skills at the beginning of the semester was average with a mean score 3.06 and SD 0.782 . The highest mean score was teamwork with mean score 3.27 and SD 0.806 . The lowest are other generic skills with a mean score 2.61 and SD 1.047. Respondent's generic skills at the end of the semester was high with a mean score 3.77 and SD 0.686 . The highest mean score is teams work with mean score 4.00 and SD 0.664. The lowest is other generic skills with a mean score 3.17 and SD 1.196. Using t-test, where $\mathrm{t}=19.363$ and $\mathrm{p}=0.00$ the findings show there is significant difference in the comparison made on GS.

\section{CONCLUSION}

In conclusion, results show that ePBL has been very effective in enhancing student's learning of both EL and GS. This has been due to the very unique tools (trigger, FILA, reflection, etc) and interactive processes 
innate of ePBL that makes the whole learning experience a dynamic one. The fact that students chose to conduct a community project as the platform for their learning of the target language using ePBL necessitated and resulted in their enhanced learning of the relevant GSs as listed in the table above. This was a case of killing not just two birds with one stone but more than just that because other than EL and GS, students had the opportunity to delve into real things in life with real people and in real setting helping them to be better prepared when facing the real world upon graduation both for employment and sustainable community development.

* Soft Skills and Generic Skills used interchangeably

\section{ACKNOWLEDGEMENT}

This research is financially supported by the Ministry of Science Technology and Innovation, Malaysia. (Grant NO. FRGS 1227)

\section{REFERENCE LIST}

B. Mohd Salleh, H. Othman, Z. Abdul Kadir, Z.A. Sayadi, M.T. Mohamed Idris, E. Anthony, R. Kamarolzaman, A. Esa, A. Selamat, F. Hamin, A. Sulaiman, A.E. Soosay (2015) Electronic ProblemBased Learning for Enhancing English Language Proficiency among Malaysian Undergraduates. Conference paper presented at ICERI 2015, Seville, Spain. 16-18 Nov 2015

Barrows, H. (1999) "Strategies for Using Case Studies in Teaching and Learning." Short Paper for a SEATEC Case Study Forum. 25 February.

Economic Planning Unit (2016) Wawasan 2020, 1991-2020. Retrieved on 1 Jan 2016 at http://www.epu.gov.my/wawasan-2020-1991-2020

JACET (2016) Chapter 2: English Language Policy in ESL Countries. (Book Chapter). Retrieved on 17 April 2016 at http://www.jacet.org/jacet50books/02.pdf

Malay Mail Online (2016) Survey: Motivated, English-Speaking Grads more likely to Find Jobs. Retrieved on 1 February 2016 at http://www.themalaymailonline.com/print/malaysia/survey-motivatedenglish-speaking-grads-more-likely-to-find-jobs

Nik Hairi Omar, Rusyda Helma Mohd and Che Arena (2012) Graduates' Employability Skills Based on Current Job Demand through Electronic Advertisement. In Asian Journal of Social Science. 8/9 July 2012 p. $103-110$

Paton, M.Q. (1990) Qualitative Evaluation and Research Methods $\left(2^{\text {nd }}\right.$ Ed.). Newbury Park, CA. Sage Publications Inc.

Prestariang Systems (2011) English Competency for Entry Level Requirement: A Market Research on Industrial Needs. Market Research Report. Selangor. Malaysia.

Reiguluth, C.M. (2000) What is a Generic Skills. Retrieved on 1 February 2016 at http://www.indiana.edu/ idtheory/methods/m7a.html

Roselina Shakir (2009) Soft Skills at the Malaysian Institute of Higher Learning. In Asia Pacific Education Review. Sep. 209, 10/3, p.309-315

Stanford University (2016) Theory Behind PBL. Retrieved on 28 April 2016 at http://ldt.stanford.edu/ jeepark/jeepark+portfolio/PBL/theory.htm

The Malaysian Times (2013) English Language and its Importance to Malaysian Growth. Retrieved on 17 April 2016 at http://www.themalaysiantimes.com.my/english-language-and-its-importance-tomalaysia\%E2\%80\%99s-growth/

The Star Online (2012) Study Reveals $\mathbf{4 0 , 0 0 0}$ Graduates are Unemployed. Retrieved on 13 June at http://www.thestar.com.my/News/Nation/2012/09/23/Study-reveals-40000-graduates-areunemployed/

The Sun Daily (2016) Tough Times for Graduates. Retrieved on 27 April 2016 at http://www.thesundaily.my/news/1499040 


\section{APPENDIX A:}

\section{COGNITIVE AND SOCIAL CONSTRUCTIVIST THEORIES UNDERPINNING PROBLEM-BASED LEARNING}

\begin{tabular}{|c|c|}
\hline $\begin{array}{l}\text { COGNITIVE CONSTRUCTIVISM } \\
\text { (PIAGET) }\end{array}$ & $\begin{array}{l}\text { SOCIAL CONSTRUCTIVISM } \\
\text { (VYGOTSKY) }\end{array}$ \\
\hline $\begin{array}{l}\text { The MIND is in the head; focus on "cognitive } \\
\text { reorganization }\end{array}$ & $\begin{array}{l}\text { The MIND is in social transactions and emerges from } \\
\text { acculturation into a community of practice }\end{array}$ \\
\hline $\begin{array}{c}\text { RAW MATERIALS; uses primary } \\
\text { data,"manipulatives," or other interactive } \\
\text { materials }\end{array}$ & $\begin{array}{l}\text { AUTHENTIC PROBLEMS; learning environments } \\
\text { reflect real-world complexities }\end{array}$ \\
\hline $\begin{array}{c}\text { STUDENT AUTONOMY; thinking and learning } \\
\text { responsibility in students' hands to foster } \\
\text { ownership }\end{array}$ & $\begin{array}{c}\text { TEAM CHOICE AND COMMON INTERESTS; builds on } \\
\text { common interests and experiences within a learning } \\
\text { group, and gives some choice to that group; learning } \\
\text { activities are "relevant, meaningful, and both product } \\
\text { and process oriented" }\end{array}$ \\
\hline $\begin{array}{l}\text { MEANINGFULNESS AND PERSONAL } \\
\text { MOTIVATION; learning related to personal } \\
\text { ideas and experiences }\end{array}$ & $\begin{array}{l}\text { SOCIAL DIALOGUE AND ELABORATION; uses } \\
\text { activities with multiple solutions, uncertainty, novelty, } \\
\text { etc, demanding dialogue, idea sharing, etc.; encourages } \\
\text { student elaboration/justification for their responses } \\
\text { through discussion, questioning, group presentations }\end{array}$ \\
\hline $\begin{array}{l}\text { CONCEPTUAL ORGANIZATION/ COGNITIVE } \\
\text { FRAMING; information organized around } \\
\text { concepts, problems, questions, themes, } \\
\text { interrelationships; activities framed within } \\
\text { thinking-related terminology }\end{array}$ & $\begin{array}{l}\text { GROUP PROCESSING AND REFLECTION; } \\
\text { encourages group processing of experiences }\end{array}$ \\
\hline $\begin{array}{l}\text { PRIOR KNOWLEDGE AND } \\
\text { MISCONCEPTIONS builds on prior knowledge } \\
\text { and addresses misconceptions }\end{array}$ & $\begin{array}{c}\text { TEACHER EXPLANATIONS, SUPPORT, \& } \\
\text { DEMONSTRATIONS demonstrates problems steps and } \\
\text { provides hints, prompts, cues, and clarifications where } \\
\text { requested }\end{array}$ \\
\hline $\begin{array}{c}\text { QUESTIONING; promotes individual inquiry } \\
\text { with open-ended questions; encourages } \\
\text { question-asking behavior }\end{array}$ & $\begin{array}{l}\text { MULTIPLE VIEWPOINTS; fosters multiple ways of } \\
\text { understanding A problem; builds in audiences beyond } \\
\text { the instructor }\end{array}$ \\
\hline
\end{tabular}

Source: Stanford University, 2016 